\title{
Hemodialysis of Patients with HCV Infection: Isolation Has a Definite Role
}

\author{
S.K. Agarwal \\ Department of Nephrology, All India Institute of Medical Sciences, New Delhi, India
}

\section{Key Words}

$\mathrm{HCV} \cdot$ Hepatitis $\cdot$ Infection control $\cdot$ Hemodialysis $\cdot$ Isolation

\begin{abstract}
$\mathrm{HCV}$ infection in patients on hemodialysis varies from 10 to $60 \%$ in various centers. There is controversy regarding the isolation of patients with $\mathrm{HCV}$ infection during hemodialysis. Guidelines developed by the Centers for Disease Control and Prevention do not suggest isolation of these patients. In this opposite view, evidence is being given to support the view that there is a definite role of isolation of HCV-infected patients during hemodialysis.

Copyright $\odot 2010$ S. Karger AG, Base
\end{abstract}

\section{Introduction}

Patients with end-stage renal disease (ESRD) on maintenance hemodialysis (MHD) are at increased risk for acquiring $\mathrm{HCV}$ infection. Prevalence of $\mathrm{HCV}$ infection varies greatly, from $<5 \%$ to nearly $60 \%$ according to different areas of the world [1]. The prevalence is consistently associated with MHD duration and the number of transfusions. With the introduction of routine HCV screening and with increased attention to prevent spread,
$\mathrm{HCV}$ prevalence has declined in many dialysis centers. However, it still remains unacceptably high, ranging from 8 to $10 \%$ even in the most industrialized countries [2]. Thus, there is still scope of reduction of HCV in MHD.

\section{HCV Spread during MHD}

HCV seroconversion had been noted in patients who were never transfused. Further, clinical experience in a dialysis unit [1], outbreaks of HCV infection in a unit [3] and phylogenetic analysis of HCV isolates $[4,5]$ all suggest that the nosocomial route of transmission plays the key role in HCV transmission. Occasionally, a ruptured dialyzer has been put forward as a potential risk for $\mathrm{HCV}$ transmission [6]. Other investigators suggested the use of a lower transmembrane pressure in patients with $\mathrm{HCV}$ infection [7]. Sartor et al. [8] provided evidence for $\mathrm{HCV}$ transmission between 2 patients sharing the same machine and suggested possible transmission via accidental contamination of the venous pressure monitoring system. Presence of HCV-RNA had been demonstrated on the hands of dialysis personnel. All these lines of evidence indicate different modes of nosocomial HCV transmission in a hemodialysis unit.

\section{KARGER}

Fax +41613061234 E-Mail karger@karger.ch www.karger.com
Fax +91 112658 8663, E-Mail skagarwal58@yahoo.co.in 
Table 1. Brief details of studies showing benefit of isolation of HCV patients in a hemodialysis unit

\begin{tabular}{|c|c|c|}
\hline Year & Authors & Main findings \\
\hline 2002 & Harmankaya et al. [12] & 168 Turk patients; HCV incidence $4.7 \%$ from 1992 to 2000 \\
\hline 2003 & Barril and Traver [15] & multicentric study in Spain \\
\hline 2003 & Yang et al. [14] & $\begin{array}{l}325 \text { Taiwanese patients; mean follow-up: } 4.8 \text { years } \\
\text { HCV incidence decreased from } 9.1 \text { to } 2.9 \%\end{array}$ \\
\hline 2003 & Saxena et al. [13] & $\begin{array}{l}189 \text { Middle East patients; follow-up: } 73 \text { months } \\
\text { HCV incidence decreased from } 6.8 \text { to } 15 \%\end{array}$ \\
\hline 2006 & Shebeb et al. [17] & $\begin{array}{l}3 \text { Egyptian dialysis units with two approaches: } \\
\text { with isolation, HCV seroconversion decreased from } 10 \text { to } 0 \% \\
\text { without isolation, incidence increased from } 10.5 \text { to } 16.7 \%\end{array}$ \\
\hline 2006 & Gallego et al. [16] & $\begin{array}{l}\text { Spanish study; isolation decreased HCV incidence from } 21.6 \% \text { in } 1995 \\
\text { to } 6.8 \% \text { in } 2003\end{array}$ \\
\hline 2008 & Alavian et al. [18] & Iranian study, HCV prevalence decreased from $14.4 \%$ in 1999 to $4.5 \%$ in 2006 \\
\hline 2009 & Ross et al. [19] & German multicentric study; no new HCV infection in 1 year \\
\hline 2009 & Agarwal et al. [21] & Indian study; isolation decreased HCV incidence from 42 to $4 \%$ from 1998 to 2006 \\
\hline 2010 & Mohamed [20] & Middle East; no HCV seroconversion in 36 patients followed for 5 years \\
\hline
\end{tabular}

\section{Practices and Policies for the Prevention of HCV in Hemodialysis Patients}

Clinical practice guidelines are systematically developed statements that aim to help physicians reach the best health care decisions. For infection control practices, guidelines developed by the US Centers for Disease Control and Prevention (CDC) are well accepted and respected. From the beginning of 1990, limited data from US studies on anti-HCV testing reported annual rates of 0.73-3\% among MHD. During 1992-1999, national surveillance data indicated that the proportion of centers that tested patients for anti-HCV increased from 22 to $56 \%$. In 1999, nationwide prevalence of anti-HCV was $8.9 \%$, with some centers reporting prevalence rates $>40 \%$ [CDC, unpubl. data; 2001]. While recommending guidelines for the prevention of infections in hemodialysis settings, CDC for the first time suggested that 'patients who are anti-HCV positive (or HCV-RNA positive) do not have to be isolated from other patients or dialyzed separately on dedicated machines. Furthermore, they can participate in dialyzer reuse programs. Unlike $\mathrm{HBV}$, $\mathrm{HCV}$ is not transmitted efficiently through occupational exposures' [9]. These recommendations were based on the premise that the infection control practices recommended for hemodialysis units will reduce opportunities for patient-to-patient transmission of infectious agents, directly or indirectly via contaminated devices, equipment and supplies, environmental surfaces or the hands of personnel. One of the important issue in 'not isolating' these patients is that universal precautions (UP) are strictly followed. UP implementation involves additional costs, knowledge about UP and commitment to adhere onto it. All the three factors with variable degree may be responsible for not having strict UP in place in many dialysis units, probably more so in developing countries. A study done in our hospital to understand the degree of knowledge about UP showed that though 100\% nurses know them, only $70 \%$ follow them in day-to-day practice [10]. Being a public sector hospital and dialysis not being supported by the government, costs may be an important issue in our setting.

\section{Evidence that Isolation Decreases HCV Seroconversion}

In the last decade, there are many studies available in the literature showing that isolation of $\mathrm{HCV}$-positive patients decreases HCV seroconversion [11-20]. Brief findings of these studies are shown in table 1. An ideal study to critically analyze the issue of isolation will consist of a 
Table 2. Comparison of different guidelines on HCV during maintenance hemodialysis

\begin{tabular}{lllll}
\hline Year & $\begin{array}{l}\text { Association/ } \\
\text { bodies }\end{array}$ & Guideline & $\begin{array}{l}\text { Grade of } \\
\text { evidence }\end{array}$ & $\begin{array}{l}\text { Recommendation for } \\
\text { isolation }\end{array}$ \\
\hline 2001 & CDC & $\begin{array}{l}\text { HCV-positive patients do not have to be isolated from other } \\
\text { patients or dialyzed separately on dedicated machines }\end{array}$ & $\begin{array}{l}\text { not } \\
\text { given }\end{array}$ & not recommended \\
\hline 2002 & $\begin{array}{l}\text { European } \\
\text { Best Practice } \\
\text { Guidelines }\end{array}$ & $\begin{array}{l}\text { in addition to universal precautions, which are the most } \\
\text { efficacious preventive measures, treatment of anti-HCV } \\
\text { patients in separate areas with dedicated staff is recommended } \\
\text { in units with a high prevalence of HCV infection }\end{array}$ & C & $\begin{array}{l}\text { recommended in units with } \\
\text { high HCV prevalence }\end{array}$ \\
\hline 2008 & $\begin{array}{l}\text { KDIGO } \\
\text { isolation of HCV-infected patients is not recommended as an } \\
\text { alternative to strict infection control procedures }\end{array}$ & weak & $\begin{array}{l}\text { in case of continued nosocomial } \\
\text { transmission, a local isolation } \\
\text { policy may be deemed necessary }\end{array}$ \\
\hline $\begin{array}{l}\text { Renal } \\
\text { Association } \\
\text { UK }\end{array}$ & $\begin{array}{l}\text { patients with HCV do not need to be dialyzed in a segregated } \\
\text { area but more experienced staff should be allocated to dialyze } \\
\text { these patients }\end{array}$ & 1C & \begin{tabular}{l} 
not recommended \\
\hline
\end{tabular} \\
\hline
\end{tabular}

randomized trial of isolation versus no isolation in a unit having two sets of dialysis areas having the same staff. Logistically being difficult, no such study has been published so far. Most of the studies have compared their own historical control. Our own study had shown that in a same unit with same staff, we could decrease HCV seroconversion from $42 \%$ in 1995-1998 (without isolation) to $4 \%$ in 2003-2006 (with isolation) [21]. As the staff and unit were the same and as no additional training for isolation practices was implemented between 1998 and 2003, we concluded that the decrease in HCV seroconversion was primarily due to isolation practices.

In the latest guidelines published in 2008 by KDIGO (Kidney Disease: Improving Global Outcomes) [22], the following points need to be given importance:

(1) Strength of recommendation that 'Isolation of HCVinfected patients is not recommended as an alternative to strict infection control procedures for preventing transmission of blood-borne pathogens' is a 'weak' one.

(2) 'If nosocomial transmission continues to occur, despite reinforcement and audit of the precautions required, a local isolation policy may be deemed necessary. HCV-infected patients should be treated by dedicated staff in a separate room, area, or shift (morning, afternoon, or evening), as there is no rationale for using dedicated machines.'

In table 2 , a comparison of different association guidelines in relation to isolation practices is given.

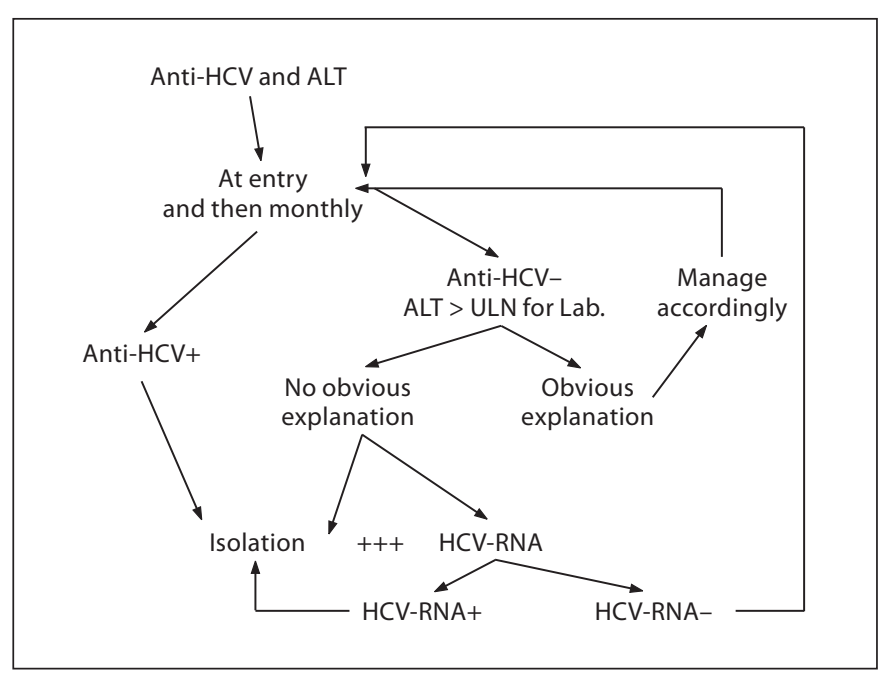

Fig. 1. Approach to HCV infection. ULN = Upper limit of normal; Lab. = laboratory.

\section{Isolate the Machine or Isolate the Patient}

Once the isolation in HCV is agreed upon, then the next issue is whether to dialyze the patient on a dedicated machine or isolate the patient. Dedicating the machine without isolation in my mind is not going to be useful. Firstly, it is mostly not the machine which is directly responsible for transmission of the virus. Secondly, remaining in same area but dedicating the staff and machine is 
practically difficult and not a dependable solution. Yang et al. [14] did an interesting study where they had three sets of patients: one set without isolation, a second set with a dedicated area and a dedicated machine in the same room and a third set of patients isolated in a separate room. Of the 325 patients followed up for the next 4 months, new HCV seroconversion was noted in 7 patients in set 1, 2 patients in set 2 and nil patients in set 3, showing that isolation in a different room was better than dedicated machines.

\section{When to Isolate?}

Third-generation anti-HCV ELISA test kits screening for HCV every 6 months are recommended by CDC. However, if there is a new seroconversion, the frequency should be increased to monthly. Along with anti-HCV, liver enzymes should also be done. There are two issues in this scenario. Firstly, anti-HCV gives false-negative tests in $10-15 \%$ cases and, secondly, liver enzymes in patients on MHD do not reflect true disease activity. In fact, in one study, normal liver enzymes during MHD are reported to be $50 \%$ of the upper limit of normal [23]. We do anti-HCV and liver enzyme testing before accepting a patient in our unit and then repeat the tests on a monthly basis. The anti-HCV, liver enzyme and HCV-RNA data are managed and interpreted as in figure 1 . We could reduce HCV incidence in our unit to almost $1-2 \%$ only.

\section{Whether or Not to Reuse Dialyzers}

CDC guidelines recommended reuse of dialyzer but the current KDIGO guidelines suggest that 'dialyzer reuse should be avoided and if this is not avoidable, then strict precautions should be taken'. As such, large numbers of centers are employing single use of dialyzer and for them it may not matter. However, in developing countries where dialyzers are reused for economic reasons, it may also be difficult to have a separate area for reuse of HCV-infected dialyzers.

\section{Conclusion}

I am not of the opinion that we should forget UP: not at all. UP will be useful for many other currently unknown blood-borne infections in the hemodialysis setting. What I am proposing is that by following UP, if a unit is not able to contain HCV infection, then they must adopt isolation of HCV-positive patients in a separate room.

\section{Disclosure Statement}

None.

\section{References}

1 Pol S, Vallet-Pichard A, Fontaine H, Lebray $P$ : HCV infection and hemodialysis. Semin Nephrol 2002;22:331-339.

-2 Meyers CM, Seeff LB, Stehman-Breen CO, Hoofnagle JH: Hepatitis $\mathrm{C}$ and renal disease: an update. Am J Kidney Dis 2003;42:631657.

-3 Castell J, Gutiérrez G: Outbreak of 18 cases of hepatitis $\mathrm{C}$ in a hemodialysis unit (in Spanish). Gac Sanit 2005;19:214-220.

-4 Spada E, Abbate I, Sicurezza E, Mariano A, Parla V, Rinnone S, Cuccia M, Capobianchi MR, Mele A: Molecular epidemiology of a hepatitis $C$ virus outbreak in a hemodialysis unit in Italy. J Med Virol 2008;80:261-267.

5 Carneiro MA, Teles SA, Lampe E, EspíritoSanto MP, Gouveia-Oliveira R, Reis NR, Yoshida CF, Martins RM: Molecular and epidemiologicalstudyon nosocomialtransmission of HCV in hemodialysis patients in Brazil. J Med Virol 2007;79:1325-1333.
6 6 Valtuille R, Fernández JL, Berridi J, Moretto $\mathrm{H}$, del Pino N, Rendo P, Lef L: Evidence of hepatitis C virus passage across dialysis membrane. Nephron 1998;80:194-196.

7 Noiri E, Nakao A, Oya A, Fujita T, Kimura S: Hepatitis $\mathrm{C}$ virus in blood and dialysate in hemodialysis. Am J Kidney Dis 2001;37:3842.

8 Sartor C, Brunet P, Simon S, Tamalet C, Berland Y, Drancourt M: Transmission of hepatitis $\mathrm{C}$ virus between hemodialysis patients sharing the same machine. Infect Control Hosp Epidemiol 2004;25:609-611.

9 Recommendation for Preventing Transmission of Infection among Chronic Hemodialysis Patients. MMWR Recommendations and Reports. Alberta, Centers for Disease Control and Prevention, 2001, vol 50.
10 Agarwal SK, Mohan MP, Varghese M: Assessment of awareness regarding universal precaution among the nursing staff of AIIMS in 1997. J Assoc Physians India 1998; 46:1061.

11 Lombardi M, Cerrai T, Geatti S, Negroni S, Pertusini L, Pegoraro M, Di Lullo G: Results of a national epidemiological investigation on HCV infection among dialysis patients. (Survey by the Italian Branch of EDTNA/ ERCA). J Nephrol 1999;12:322-327.

$\checkmark 12$ Harmankaya O, Cetin B, Obek A, Seber E: Low prevalence of hepatitis $C$ virus infection in hemodialysis units: effect of isolation? Ren Fail 2002;24:639-644.

13 Saxena AK, Panhotra BR, Sundaram DS, Naguib M, Venkateshappa CK, Uzzaman W, Mulhim KA: Impact of dedicated space, dialysis equipment, and nursing staff on the transmission of hepatitis $\mathrm{C}$ virus in a hemodialysis unit of the Middle East. Am J Infect Control 2003;31:26-33. 
- 14 Yang CS, Chang HH, Chou CC, Peng SJ: Isolation effectively prevents the transmission of hepatitis $\mathrm{C}$ virus in the hemodialysis unit. J Formos Med Assoc 2003;102:79-85.

15 Barril G, Traver JA: Decrease in the hepatitis $\mathrm{C}$ virus (HCV) prevalence in hemodialysis patients in Spain: effect of time, initiating HCV prevalence studies and adoption of isolation measures. Antiviral Res 2003;60:129134.

16 Gallego E, López A, Pérez J, Llamas F, Lorenzo I, López E, Illescas ML, Andrés E, Olivas E, Gómez-Roldan C: Effect of isolation measures on the incidence and prevalence of hepatitis $\mathrm{C}$ virus infection in hemodialysis. Nephron Clin Pract 2006;104:c1-c6.
7 Shebeb AM, Kotkat AM, Abd El Reheim SM, Farghaly AG, Fetohy EM: An intervention study for prevention of $\mathrm{HCV}$ infection in some hemodialysis units in Alexandria. J Egypt Public Health Assoc 2006;81:119-141.

18 Alavian SM, Bagheri-Lankarani K, Mahdavi-Mazdeh M, Nourozi S: Hepatitis B and C in dialysis units in Iran: changing the epidemiology. Hemodial Int 2008;12:378-382.

19 Ross RS, Viazov S, Clauberg R, Wolters B, Fengler I, Eveld K, Scheidhauer R, Hüsing J, Philipp T, Kribben A, Roggendorf M: Lack of de novo hepatitis $\mathrm{C}$ virus infections and absence of nosocomial transmissions of GB virus $\mathrm{C}$ in a large cohort of German haemodialysis patients. J Viral Hepat 2009;16:230 238.

-20 Mohamed WZ: Prevention of hepatitis C virus in hemodialysis patients: five years experience from a single center. Saudi J Kidney Dis Transpl 2010;21:548-554.
21 Agarwal SK, Dash SC, Gupta S, Pandey RM: Hepatitis $\mathrm{C}$ virus infection in haemodialysis: the 'no-isolation' policy should not be generalized. Nephron Clin Pract 2009;111:c133c140.

22 Preventing HCV transmission in hemodialysis units. Kidney Int 2008;73(suppl 109): S46-S52.

$>23$ Lopes EP, Gouveia EC, Albuquerque AC, Sette LH, Mello LA, Moreira RC, Coelho MR: Determination of the cut-off value of serum alanine aminotransferase in patients undergoing hemodialysis, to identify biochemical activity in patients with hepatitis $\mathrm{C}$ viremia. J Clin Virol 2006;35:298-302. 